\title{
Optimization of structural brickwork laying joints in concrete blocks
}

\section{Otimização das juntas de assentamento de alvenaria estrutural em blocos de concreto}
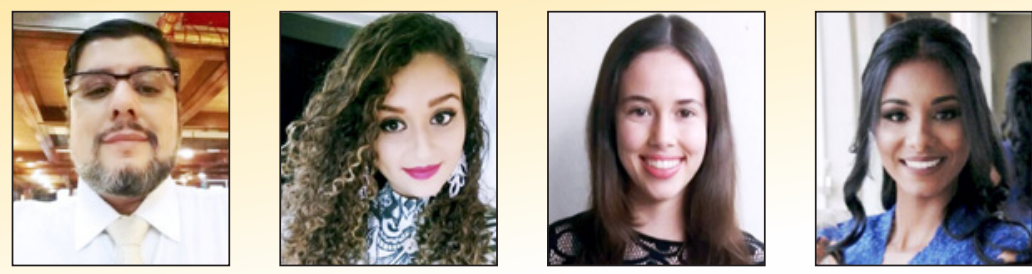

\author{
M. V. S. CAVALCANTI a, b \\ marvinscav@gmail.com
}

A. M. X. FRANCISCO andressa.mx@hotmail.com

D. M. RODRIGUES a dalilaengenharia@gmail.com

D. G. SILVA a deboragodoi_g@hotmail.com

\begin{abstract}
One of the challenges in the investigation of structural masonry is the correlation between the thickness of the laying joints and the global resistance of the masonry. Many authors developed experimental correlations in the attempt to establish an analytical relation between the joint thickness and the resistance of the masonry. All these projects indicate that there are many parameters and considerations to be analyzed in the understanding this relation and in understanding the collapse of the masonry as a whole. Thus, in an attempt to contribute with this field of study, the present paper investigates the influence of the thickness of the mortar laying joint in the resistance of the masonry structure.

With the objective of experimentally establishing a relation between the joint thickness and the resistance of the masonry, rupture trials were held to the axial compression of three block prisms laid with five series of thicknesses: $8 \mathrm{~mm}, 12.5 \mathrm{~mm}, 10 \mathrm{~mm}, 15 \mathrm{~mm}$ and $20 \mathrm{~mm}$. The physical and mechanic description of all the components that made up the masonry were done separately, complying with the regulations.

Through a simplified statistical analyses, presented at the end of this study, values of resistance of each series of prisms associated to a specific thickness for the laying joint are shown. Through the comparison of the specific results of the analyzed specimen, we arrived at the suggestion of a better performance joint and it was also possible to establish a behavioral tendency, through the comparison of results, helping in the understanding of how the block-joint set behave monolithically from the determination of the individual characteristics of each element. Which is one of the keys that will permit the constructions of a behavioral model capable of assisting structural analysts in their structural masonry dimensioning techniques.
\end{abstract}

Keywords: structural masonry, concrete blocks, laying joints.

\section{Resumo}

Um dos desafios na investigação do comportamento da alvenaria estrutural é a correlação entre a espessura da junta de assentamento e a resistência global da alvenaria. Vários autores desenvolveram correlações experimentais na tentativa de estabelecer uma relação analítica entre a espessura da junta e a resistência da alvenaria. Todos esses trabalhos indicam que existem muitos parâmetros e considerações a serem analisadas no entendimento dessa relação e no entendimento do colapso da alvenaria como um todo. Assim, pretendendo contribuir com esse campo de pesquisa, o presente trabalho investiga a influência da espessura da junta argamassa de assentamento na resistência da alvenaria estrutural. Com o objetivo de estabelecer experimentalmente uma relação entre a espessura da junta e a resistência da alvenaria realizaram-se ensaios de ruptura à compressão axial em prismas de três blocos assentados com cinco séries de espessuras: $08 \mathrm{~mm}, 12,5 \mathrm{~mm}, 10 \mathrm{~mm}, 15 \mathrm{~mm}$ e $20 \mathrm{~mm}$. E a caracterização física e mecânica de todos os componentes que constituem a alvenaria foi realizada isoladamente, atendendo as normas. Através de uma análise estatística simplificada, apresentada ao final do presente trabalho são mostrados os valores de resistência de cada série de prismas associados a uma espessura específica para junta de assentamento. Através da comparação entre os resultados específicos dos corpos de prova analisados, chegou-se a sugestão de uma junta de melhor desempenho e também foi possível estabelecer uma tendência de comportamento, auxiliando a compreender como o conjunto bloco-junta se comporta monoliticamente a partir da determinação das características individuais de cada elemento. O que é uma das chaves que permitirá construir um modelo de comportamento capaz de auxiliar os analistas estruturais em suas técnicas de dimensionamento da alvenaria estrutural.

Palavras-chave: alvenaria estrutural, blocos de concreto, juntas de assentamento. 


\section{Introduction}

Structural brickwork is a constructive process, in which components are used to seal the construction and to resist forces simultaneously. Although it's a millennial technique, the labor-saving use with dimension and calculous methodology is recent. Nowadays, with the advancement of techniques and material, in addition to the governmental impulse towards habitation construction, brickwork has been applied more often, for it presents benefits such as, easiness of execution, rationality and resource reduction in the project execution [1].

The structural masonry is designed to withstand stress, it has excellent ability to withstand the compression demands; however, for tensile stresses, its strength is much lower, and in some cases, it is necessary to use grate and reinforced. In this sense the material quality and thickness of the laying joint is fundamental, considering that the traction efforts that generally provoke block collapse begin in the superior or/and inferior sides of the block, exactly on connecting sides between one block and the other [1].

The main parameter for the dimensioning of the brickwork is in its resistance to compression that plays a role in the quality and resistance of its constituent components: the block and laying mortar, as well as the thickness of the joints. In Brazil, the use of hollow concrete blocks and the laying with a mixture of mortar and chalk gained popularity, the Brazilian standard NBR 15961-1 [2] recommends the use of joints with thickness of $10 \mathrm{~mm}$ with variation of $+-3 \mathrm{~mm}[3]$.

Many authors such as Medeiros and Sabbatini [4], Freitas [5] studied the prisms' behavior as to the joint thickness function and verified that the increase of the thickness causes a considerable reduction to the brickwork's resistance. However Mohamed [6] highlights that a loss of the mortar's deformation absorption capacity may occur if the joint reduction is excessive, and the increase of tension on the points where the block sides connect.

Duarte [7] rejects the above joints of $15 \mathrm{~mm}$, because he considers that they cause an increase in cost and a reduction of the brickwork's resistance; due to the fact that the mortar is the weakest part of the brickwork.

At the end of the present paper, it is shown the resistance value of each series of prisms associated to a specific thickness for the laying joint. Through the comparison of specific results of the trial bodies analyzed, we arrived at a suggestion of a better performance joint and it was also possible to establish a behavioral tendency through the comparison of results.

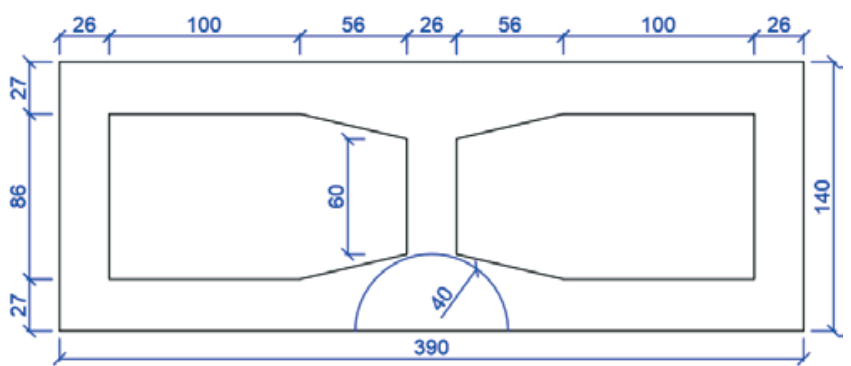

Figure 1

Studied commercial block face dimension ( $\mathrm{mm}$ )

\section{Material and experimental program}

The experimental program of the present work is inserted in a line of research that studies the efficiency and integrity of structural masonry. With regard to the optimization of joints, this research line has been studying the variation of traces and thicknesses since the works of Oliveira [8] (2006), Oliveira [9] (2014), Bandeira [10] (2014), Souza and Nunes [11] (2015), Francisco and Soares [12] (2016); allowing the construction of a database that correlates the different joint thicknesses with the mechanical and service performance of the masonry. Thus, this work, in addition to using the results collected will contribute with new data for continuity of the line of research through future work.

\subsection{Dimensional description of the blocks}

The blocks used in this study were acquired at a regional factory of pre-molded blocks, in order to study the same blocks that are commercially used by local construction companies. A dimensional analysis was done for these blocks and a visual inspection in accordance with orientation of the NBR (Brazilian Association of Technical Standards) 6136 [13], through which was verified that they did not present any defect or pathology that would compromise the trials.

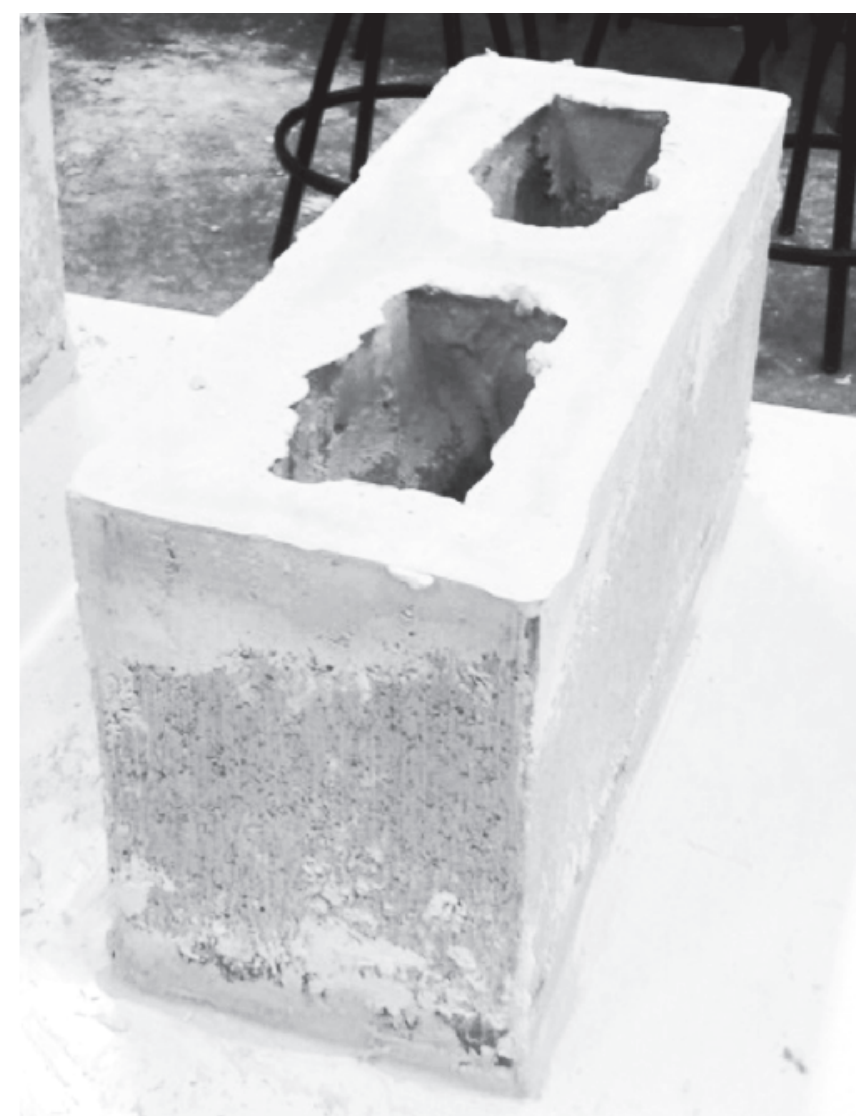

Figure 2

Block with plaster capping 
In a random sample of 10 blocks the length, height and width of the transversal and longitudinal walls were verified, as presented in Figure 1. The weight was determined in a digital precision scale, weighing at around $122 \mathrm{~N}$.

None of the blocks of the sample presented a dimension that exceeded the tolerance allowed by the NBR 6136 [13] which is, $\pm 2 \mathrm{~mm}$ for the width and $\pm 3 \mathrm{~mm}$ for height and length, therefore the block can be categorized as belonging to the $15 \times 40$ family, with corbel. The brute section area of the block is $546 \mathrm{~cm} 2$ and the liquid section area (brute section area minus the hollowed out holes) is $292.24 \mathrm{~cm} 2$. The volume was geometrically determined by multiplying the liquid section area by the block height, coming out to $5552.56 \mathrm{~cm} 3$. Ergo the specific mass has the value of $2186,38 \mathrm{~kg} / \mathrm{m}^{3}$ and is in accordance to NBR 6118 [14].

\section{2 Mechanical description of the blocks}

For the trial of axial compression, 12 block were chosen randomly of a lot of 200 . Before the trial they undertook a regularization treatment of the superior and inferior sides with plaster, known as capping as shown in Figure 2; in which the paste mixed with $2 \mathrm{~kg}$ of gypsum powder, glue and 1 Liter of water is applied with a help of a spatula, next the block is positioned on a table greased with vegetable oil where it's leveled. In accordance to NBR 6136 [13] the width of the capping layer did not exceed $3 \mathrm{~mm}$.

The capping serves the purpose of helping distribute the tension uniformly over the whole block and to avoid the concentration of isolated points. In addition to capping two $3 \mathrm{~mm}$ sheets of cork were used during the severance. The plaster-cork set provided a compression force uniformity, minimizing the tangential efforts to the cargo application plain, which reduces the collapse possibility by tangential sheering on the top or bottom of the block [1]. Figure 3 shows the block's rupture scheme.

The rupture was made in accordance to the NBR 12118 [15] procedures, using a universal trial machine of the brand Con-

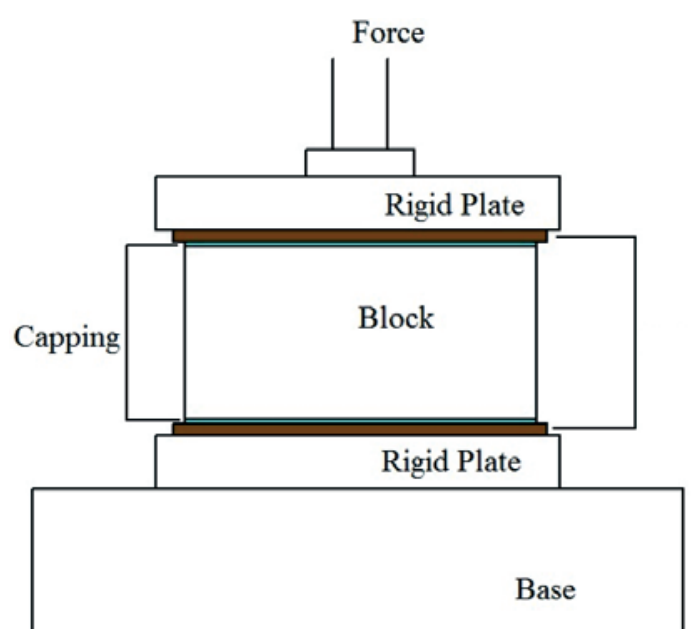

Figure 3

Axial compression trial procedure scheme with trial machine tenco Pavitest with a maximum capacity of $100 \mathrm{tf}$. The squeezer was equipped with two rigid plates and the cargo increment was automatically applied at a speed of $0,25 \mathrm{MPa} / \mathrm{s}$. Figure 4 shows the block during trial.

Of the 12 trialed blocks, the two highest and two lowest rupture tensions presented were discarded, leaving an 8 block set, with a more uniform rupture tension distribution. Simplified statistical analyses were done on the 8 remaining values that provided an average and characteristic value to the block's rupture tension that were used on further analyses of this project. This analysis is shown on Table 1 and Table 2, where fbm is the average tension to the simple compression of the block, fbk is the characteristic tension to the simple compression of the block, and Sd is the standard deviation. In accordance to the NBR 6136 [13], the blocks may be classified as belonging to Class $B$ with structural function, namely, its average characteristic resistance (fbm) in relation to the brute area sits between $4 \mathrm{MPa}$ and $8 \mathrm{MPa}$.

\subsection{Description of the fine aggregate}

According to Roman [16] the fine sands are preferable for making the structural brickwork laying mortar, due to the fact that they provide more adherence to the mortar. The aggregate used in this study is a local river washed sand, presenting a maximum diameter characteristic of $2.63 \mathrm{~mm}$ and the fineness module is 2.86, it was trialed in accordance to NBR 248 [11]. Figure 5 shows the results of the granulometry of the aggregate utilizing the Utilization Zone Limits established by NBR 7211 [18].

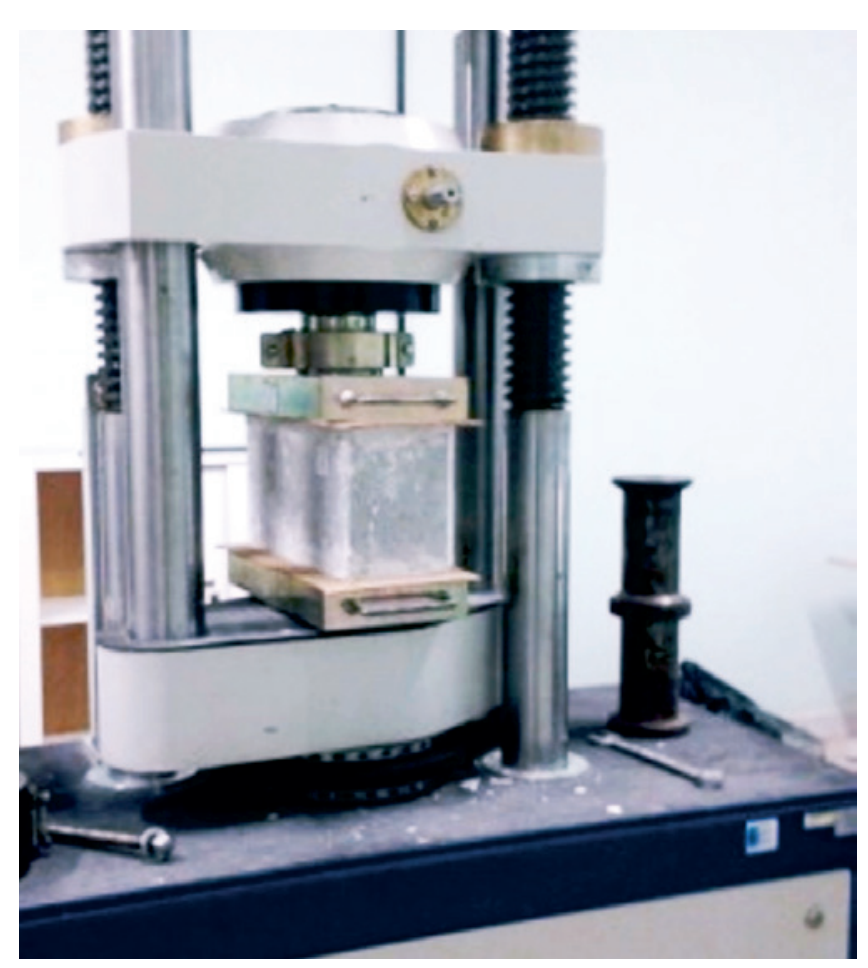

Figure 4

Block axial compression trial 
Table 1

Block compression trial results (Brute area $=546 \mathrm{~cm}^{2}$ )

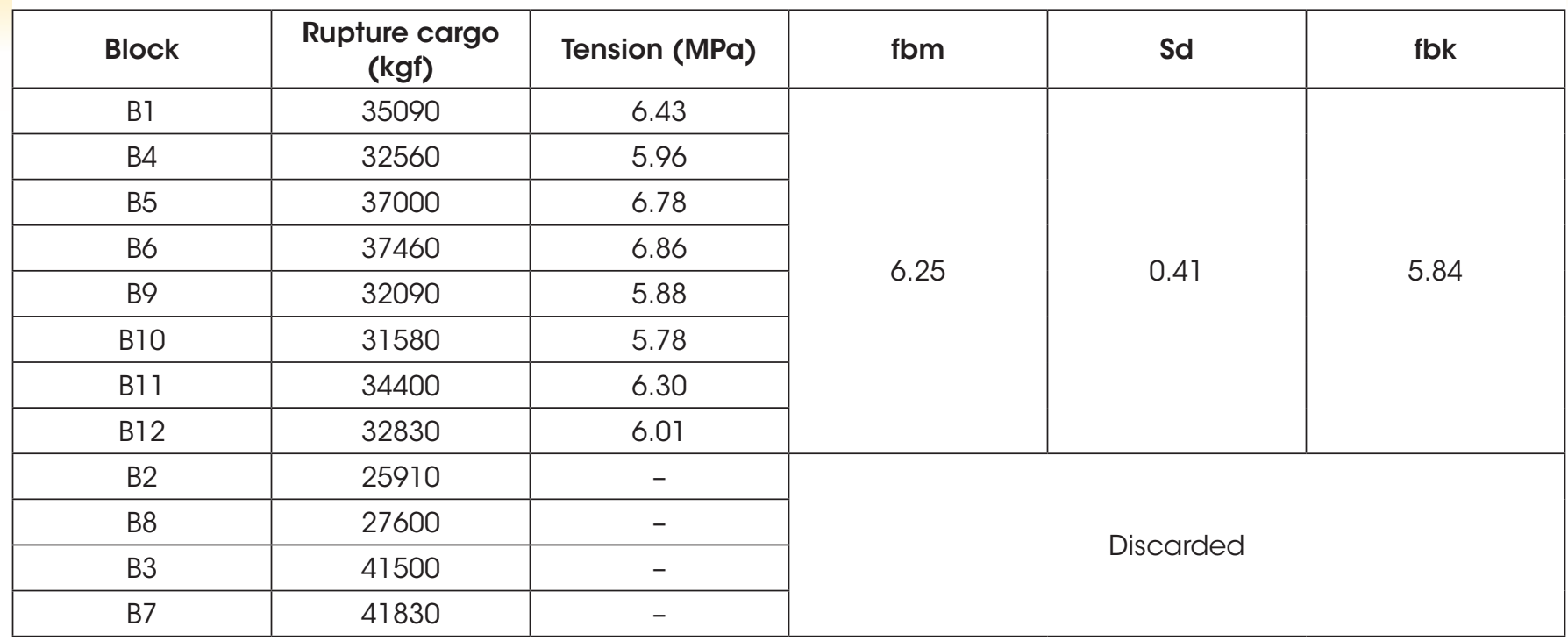

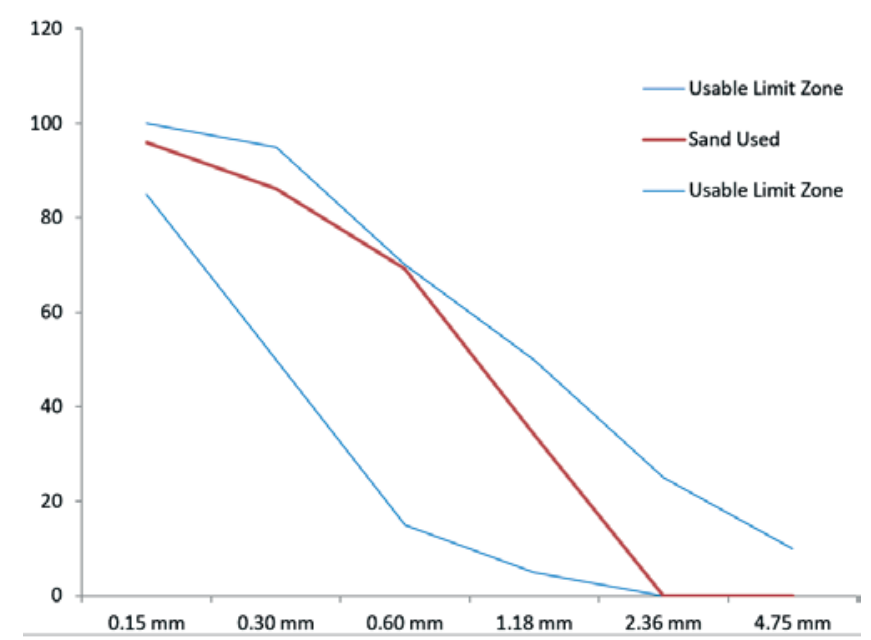

Figure 5

Granulometric composition graphic of the fine aggregate used for the mortar

\subsection{Mechanical description of the laying mortar}

The mortar used in the prisms' assembly is mixed and built on the spot, with a 1:0.4:5.72 (cement: chalk: sand) trait, with a weight and water to cement ratio of 1.6. The choice of the trait was made by taking in to consideration the frequency of the use of structural brickwork in regional construction. Cement CP II Z-32 was used, $\mathrm{CH}$ III hydrated chalk and medium washed sand. The trait was corrected in the mortar preparation due to the humidity of the sand, the mixture was done in a concretemixer, then the consistency and workability was visually verified.

For the mortar compression resistance verification, six proof bodies were molded in the dimension of $5 \times 10 \mathrm{~cm}$, in accordance to NBR 7215 [19]. The rupture trials were held in the same test machine used for the block trials. Table 3 shows the proof bodies rupture cargos submitted to the compression test, the individual and average rupture tension, the standard deviation (Sd), as well as the characteristic resistance description of the mortar (farg).

\subsection{Prism compression trials}

The prisms' axial compression trials were held in order to evaluate the resistance capacity of the brickwork for each thickness of the laying joints. These trials were held in accordance to NBR 15961-2 [20] and NBR 12118 [15].

Table 2

Block compression trial results (Liquid area $=292.24 \mathrm{~cm}^{2}$ )

\begin{tabular}{|c|c|c|c|c|c|}
\hline Block & $\begin{array}{l}\text { Rupture cargo } \\
\text { (kgf) }\end{array}$ & Tension (MPa) & $\mathrm{fbm}$ & Sd & fbk \\
\hline B1 & 35090 & 12.01 & \multirow{8}{*}{11.68} & \multirow{8}{*}{0.77} & \multirow{8}{*}{10.91} \\
\hline B4 & 32560 & 11.14 & & & \\
\hline B5 & 37000 & 12.66 & & & \\
\hline B6 & 37460 & 12.82 & & & \\
\hline B9 & 32090 & 10.98 & & & \\
\hline B10 & 31580 & 10.81 & & & \\
\hline B11 & 34400 & 11.77 & & & \\
\hline $\mathrm{B} 12$ & 32830 & 11.23 & & & \\
\hline
\end{tabular}


Table 3

Mortar proof bodies compression trial results (Section area $=19.63 \mathrm{~cm}^{2}$ )

\begin{tabular}{|c|c|c|c|c|c|}
\hline Proof body & $\begin{array}{c}\text { Rupture cargo } \\
\text { (kgf) }\end{array}$ & Tension (MPa) & fma (MPa) & Sd & farg (MPa) \\
\hline 1 & 500 & 2.55 & \multirow{6}{*}{2.36} & \multirow{6}{*}{0.36} & \multirow{6}{*}{2.00} \\
\hline$\|$ & 480 & 2.45 & & & \\
\hline III & 490 & 2.50 & & & \\
\hline IV & 500 & 2.55 & & & \\
\hline $\mathrm{V}$ & 320 & 1.63 & & & \\
\hline $\mathrm{Vl}$ & 490 & 2.50 & & & \\
\hline
\end{tabular}

50 prisms of 3 blocks were assembled, with five different laying joint thickness. Although some authors use two blocks prisms, it's been adopted in this work the use of three blocks prisms, since this procedure was more adequate in obtaining results closer to the reality of the masonry reality by approaching more of the real configuration of masonry. Awareness was given to the possible variables that could interfere in the prisms' resistance, such as, skilled labor, thickness execution templates, plummet and flatness. The blocks were previously dampened in order to avoid the mortar's water absorption.
After assembly, the prisms were identified and undertook a 14-day curation period, after they were submitted to compression trials under the same contour conditions of the block compression trials, as shown in Figure 6.

\section{Results and discussions}

\subsection{On the prism trials}

On Tables $4,5,6,7$, and 8 the rupture cargo for each prism is

Table 4

$20 \mathrm{~mm}$ laying joint thickness prisms

\begin{tabular}{|c|c|c|c|c|c|}
\hline Prisms & $\begin{array}{c}\text { Rupture cargo } \\
\text { (kgf) }\end{array}$ & Tension (MPa) & fpm (MPa) & Sd & fpk (MPa) \\
\hline 2 & 11040 & 3.80 & \multirow{6}{*}{3.47} & \multirow{6}{*}{0.39} & \multirow{6}{*}{3.07} \\
\hline 3 & 8600 & 2.90 & & & \\
\hline 4 & 9150 & 3.10 & & & \\
\hline 7 & 11510 & 3.90 & & & \\
\hline 9 & 10230 & 3.50 & & & \\
\hline 10 & 10440 & 3.60 & & & \\
\hline 1 & 13710 & 4.70 & & \multirow{4}{*}{ Discarded } & \\
\hline 5 & 7340 & 2.50 & & & \\
\hline 6 & 13800 & 4.70 & & & \\
\hline 8 & 7410 & 2.50 & & & \\
\hline
\end{tabular}

\section{Table 5}

$10 \mathrm{~mm}$ laying joint thickness prisms

\begin{tabular}{|c|c|c|c|c|c|}
\hline Prisms & $\begin{array}{c}\text { Rupture cargo } \\
\text { (kgf) }\end{array}$ & Tension (MPa) & fpm (MPa) & Sd & fpk (MPa) \\
\hline 11 & 22090 & 7.60 & \multirow{6}{*}{7.03} & \multirow{6}{*}{0.84} & \multirow{6}{*}{6.19} \\
\hline 12 & 23830 & 8.20 & & & \\
\hline 13 & 18220 & 6.20 & & & \\
\hline 15 & 17510 & 6.00 & & & \\
\hline 17 & 21380 & 7.30 & & & \\
\hline 19 & 20020 & 6.90 & & & \\
\hline 14 & 32030 & 11.00 & & \multirow{4}{*}{ Discarded } & \\
\hline 16 & 10360 & 3.50 & & & \\
\hline 18 & 14330 & 4.90 & & & \\
\hline 20 & 26870 & 9.20 & & & \\
\hline
\end{tabular}


shown, the individual rupture tension values and the average rupture tension value for the associated prism set (fpm) according each laying joint thickness. In order to calculate the average tension of each thickness group, the same procedure was adopted as the one used in the blocks, characterized by discarding the values of the two largest and the two lowest burst stresses presented, it

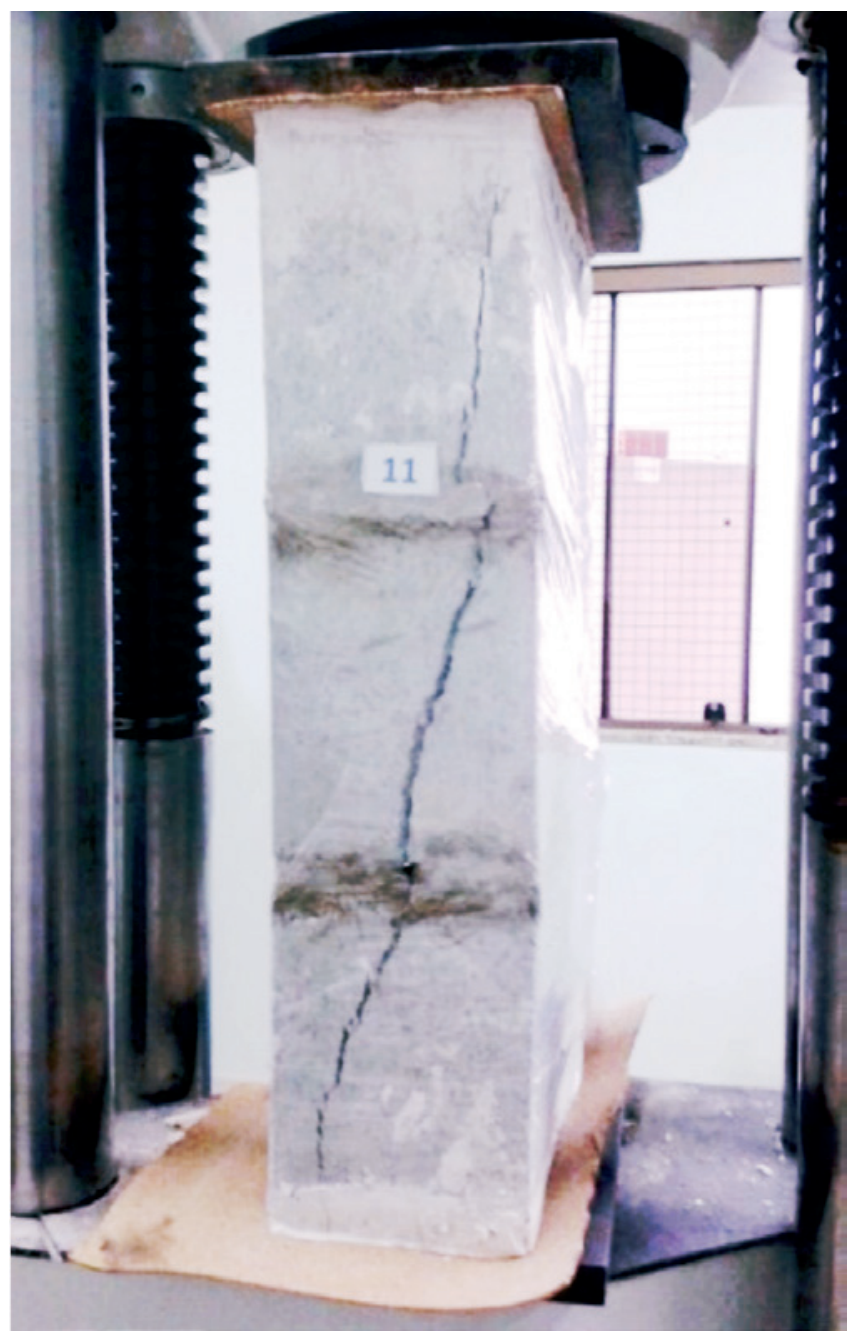

\section{Figure 6}

Axial compression trial of three block laid prisms

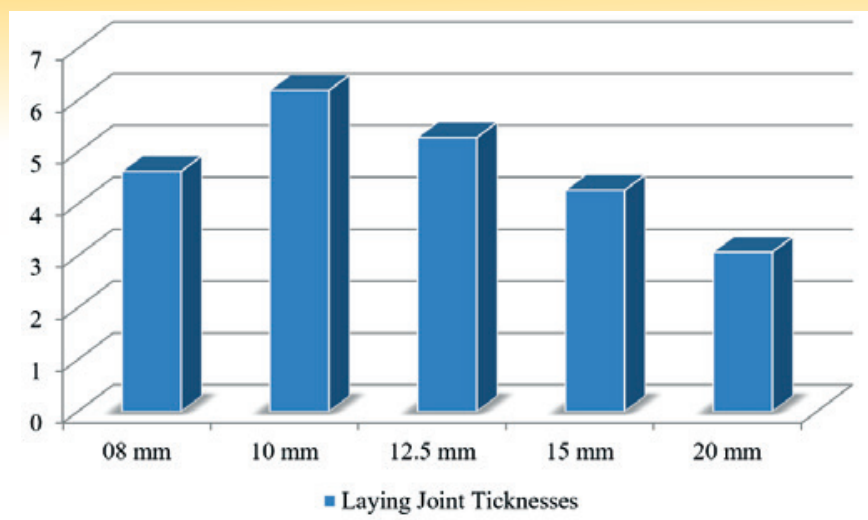

Figure 7

Performance comparative graph of joint related prisms with different thicknesses

provided a more uniform statistical distribution, composed of a set of 6 prisms. The characteristic resistance value of simple compression of each series of prisms (fpk) is also shown.

\subsection{Tendency}

The results relative to the avarege resistance to compression of the structural brickwork prisms (fpm) for the different thickness joints, as well as the standard deviation (Sd) and characteristic resistance (fpk) are shown on Table 9.

The results of the relation between the prism ruptures and the joint thickness, follow the tendency shown by Ramalho e Corrêa [3], Medeiros [4] e Mohamad [6], where it is verified that the bigger the thickness the lower is the resistance achieved by the set. In this project, in addition to verifying this behavior, an investigation on what occurs with the unusual thickness of $8 \mathrm{~mm}$, that also suffers from a loss of resistance was performed. This tendency can be evidenced on Figure 7.

\subsection{Efficiency}

The brickwork efficiency is obtained by the reason between the prism resistance (fpk) and the block characteristic resistance (fbk). Table 10 shows the value of the brickwork's efficiency for the prisms tested in this project. The ideal efficiency according to

\section{Table 6}

$8 \mathrm{~mm}$ laying joint thickness prisms

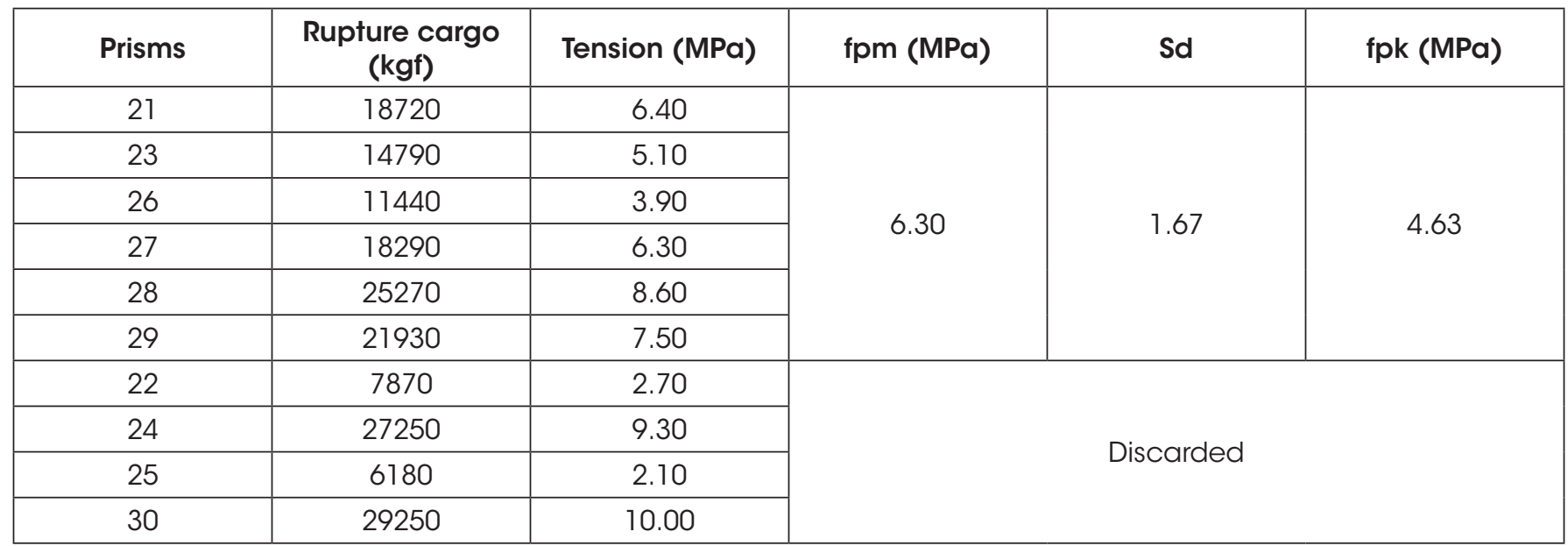


Table 7

$12.5 \mathrm{~mm}$ laying joint thickness prisms

\begin{tabular}{|c|c|c|c|c|c|}
\hline Prisms & $\begin{array}{l}\text { Rupture cargo } \\
\text { (kgf) }\end{array}$ & Tension (MPa) & fpm (MPa) & Sd & fpk (MPa) \\
\hline 32 & 20250 & 6.90 & \multirow{6}{*}{6.35} & \multirow{6}{*}{1.07} & \multirow{6}{*}{5.28} \\
\hline 35 & 12770 & 4.40 & & & \\
\hline 36 & 18580 & 6.40 & & & \\
\hline 38 & 17620 & 6.00 & & & \\
\hline 39 & 20660 & 7.10 & & & \\
\hline 40 & 21360 & 7.30 & & & \\
\hline 31 & 23710 & 8.10 & & \multirow{4}{*}{ Discarded } & \\
\hline 33 & 10070 & 3.40 & & & \\
\hline 34 & 9990 & 3.40 & & & \\
\hline 37 & 22340 & 7.60 & & & \\
\hline
\end{tabular}

Table 8

$15 \mathrm{~mm}$ laying joint thickness prisms

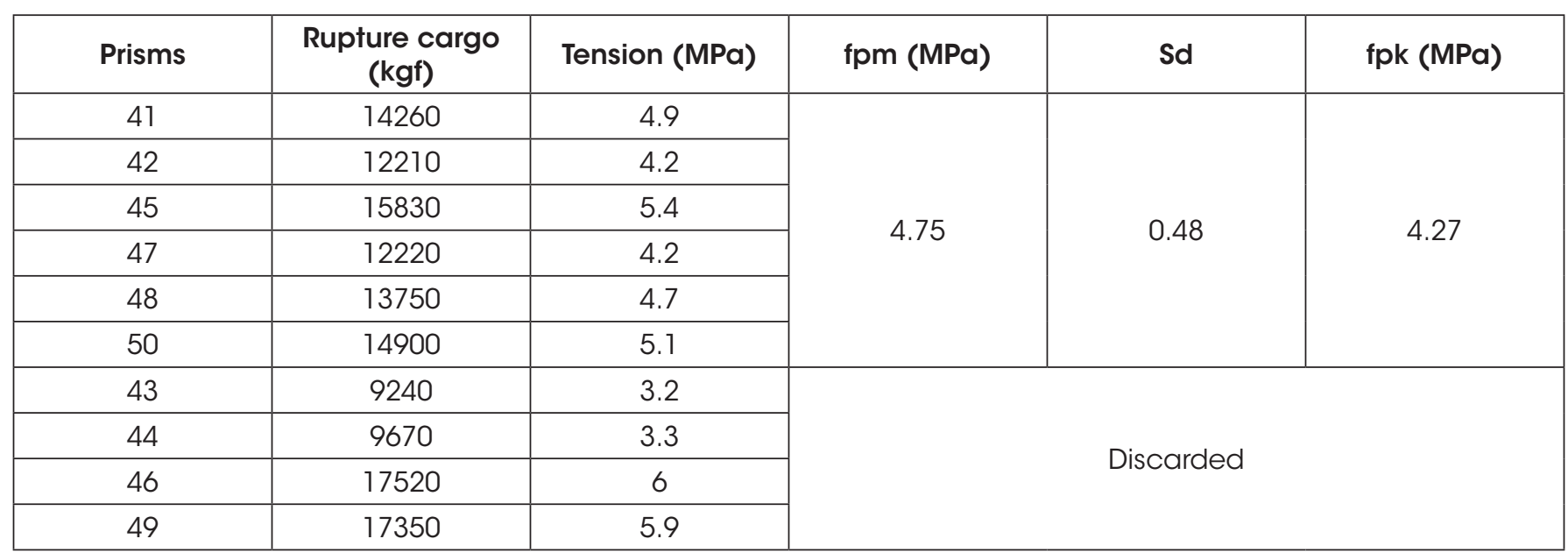

Camacho [21], should present values between 0.50 to 1.00 . Among the prism series investigated, the one that presented a superior efficiency level to the minimum required by Camacho [21] was laid with a $10 \mathrm{~mm}$ joint. This verification follows the tendency presented in Figure 7, where the thickness of $10 \mathrm{~mm}$ was the one that presented the best result for the prism resistance. However, [15] does not offer further detail as to how the block and prism resistance are singly obtained.

According to Mohamad [6] the mortar resistance and the block resistance to compression should be compatible, if not it would result in a brickwork efficacy loss.

\section{Table 9}

Joint related results

\begin{tabular}{|c|c|c|c|}
\hline Thickness & fpm (MPa) & Sd & fpk (MPa) \\
\hline $8 \mathrm{~mm}$ & 6.30 & 1.67 & 4.63 \\
\hline $10 \mathrm{~mm}$ & 7.03 & 0.84 & 6.19 \\
\hline $12.5 \mathrm{~mm}$ & 6.35 & 1.07 & 5.28 \\
\hline $15 \mathrm{~mm}$ & 4.75 & 0.48 & 4.27 \\
\hline $20 \mathrm{~mm}$ & 3.47 & 0.39 & 3.07 \\
\hline
\end{tabular}

\section{$3.48 \mathrm{~mm}$ thickness behavior}

This is the thickness that provides the biggest saving due to the lower use of mortar quantity. However, the saving generated by the reduction of the joint thickness should not be considered, for along with it comes a $25 \%$ loss of resistance in relation to the $10 \mathrm{~mm}$ thickness.

\section{$3.510 \mathrm{~mm}$ thickness behavior}

This presented the best mechanical behavior with a considerable

Table 10

Joint related prism efficiency

\begin{tabular}{|c|c|c|c|}
\hline Thickness & fpk (MPa) & fbk (MPa) & fpk/fbk \\
\hline $8 \mathrm{~mm}$ & 4.63 & \multirow{5}{*}{10.91} & 0.42 \\
\hline $10 \mathrm{~mm}$ & 6.19 & & 0.57 \\
\hline $12.5 \mathrm{~mm}$ & 5.28 & & 0.48 \\
\hline $15 \mathrm{~mm}$ & 4.27 & & 0.39 \\
\hline $20 \mathrm{~mm}$ & 3.07 & & 0.28 \\
\hline
\end{tabular}


elevated resistance when compared to the lowest resistance. It's the most useful thickness from a structural, economical and executional point of view. If compared to the $8 \mathrm{~mm}$ thickness the rise in mortar consumption is insignificant if the gain in resistance is taken under consideration.

\section{6 $12.5 \mathrm{~mm}$ thickness behavior}

This has a high difficulty level of execution in construction sites. When compared to the $10 \mathrm{~mm}$ thickness there's a decrease in resistance and an increase in mortar consumption.

\section{7 $15 \mathrm{~mm}$ thickness behavior}

It is used in structural brickwork construction sites in the Anápolis$\mathrm{GO}$ region due to the low difficulty level of execution .However, in this study the prisms laid with this thickness presented a mortar graining tendency and low resistance; furthermore, the thickness may be considered economically inviable.

\subsection{0mm thickness behavior}

It was observed that many prisms of the $20 \mathrm{~mm}$ group presented mortar graining during compression as shown in Figure 8. Such behavior is due to lower tension of confinement in which the mortar is submitted.

\subsection{Comparative presentment of the trialed prisms}

On the basis of the hypothesis that the $10 \mathrm{~mm}$ thickness is the best thickness, Table 11 was made to show the comparison of the prism sets resistance, having this thickness as the foundation. It can be evidenced in Figure 9 that the rise and/or saving of laying mortar is not proportional to the resistance variation. All of the tested thicknesses presented a significant decrease in resistance in relation to the $10 \mathrm{~mm}$ thickness.

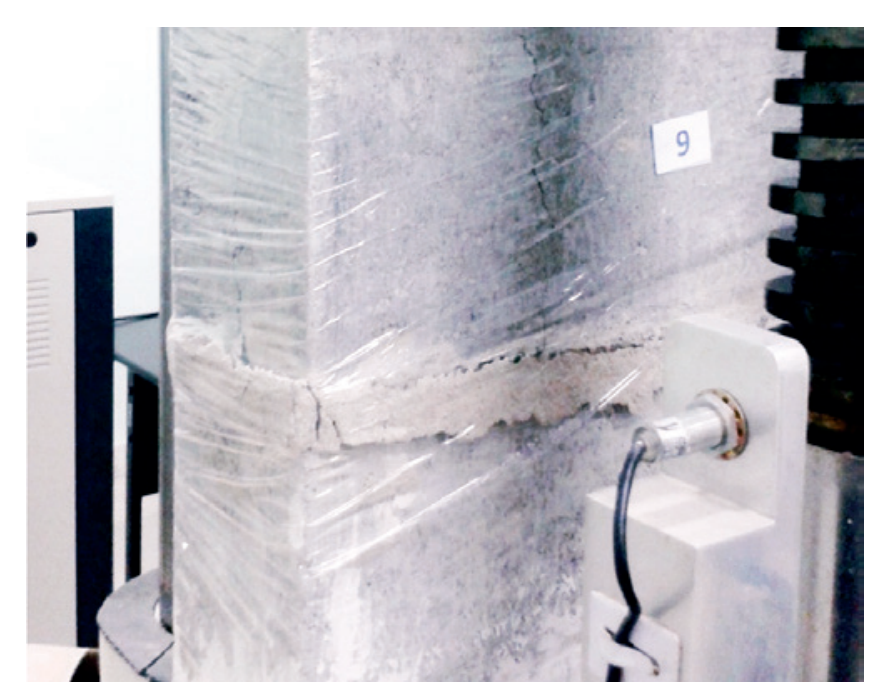

Figure 8

$20 \mathrm{~mm}$ thick joints of laid prisms, presents mortar graining characteristic to this series

\section{Conclusion}

Out of all the thicknesses studied the $10 \mathrm{~mm}$ present a higher resistance and efficiency of the brickwork. The three block prisms presented results that are closer to the brickwork's behavior. The behavioral tendencies of the prisms as to the joint thickness presented in this project are in accordance with the results of Castro [22] and Vicente et.al [23]. It's necessary to further investigate the behavior of the prisms with joint thicknesses lower than $10 \mathrm{~mm}$, since this project only investigated a series of $8 \mathrm{~mm}$. The presented results were obtained with the block resistance approximately five times greater than the mortar resistance, making it necessary to repeat the trial series with other mortar traits to verify if the same tendency repeats itself with more resistant mortars.

\section{Acknowledgements}

The development of this research was made possible through research funds granted by CNPQ and FUNDADESP/UniEvangélica and of blocks supplied by VIBRACOM company. In addition to the facilities and equipment from the Civil Engineering Lab of UNUCET/UEG and the Technology Center of UniEvangélica, as well as the collaboration of their respective technicians.

\section{Bibliographical references}

[1] CAVALCANTI, Marcus Vinícius Silva. Avaliação do processo de ruptura em blocos de concreto considerando os aspectos dinâmicos. 155p. 2011. Tese (Doutorado Estruturas e Construção Civil) - Departamento de Engenharia Civil e Ambiental, Universidade de Brasília, Distrito Federal, 2011.

[2] ASSOCIAÇÃO BRASILEIRA DE NORMAS TÉCNICAS. alvenaria estrutural: blocos de concreto: parte 1: projeto. NBR 15961 - 1: Rio de Janeiro, 2011.

[3] RAMALHO, M. A.; CORRÊA, M. R. S. Projeto de edifícios de alvenaria estrutural. São Paulo: Editora Pini, 2003.

[4] MEDEIROS, Jonas Silvestre; SABBATINI, Fernando Henrique. Alvenaria estrutural não armada de blocos de concreto: produção de componentes e parâmetros de projeto. 1993. 20f. Boletim Técnico da Escola Politécnica da Universidade de São Paulo - Departamento de Engenharia da Construção Civil, São Paulo, 1993.

[5] FREITAS, A. A. (2008). Numerical and experimental analysis of the behavior of prisms and mini-walls under compression.

Table 11

$10 \mathrm{~mm}$ thickness related resistance variation

\begin{tabular}{|c|c|c|}
\cline { 2 - 3 } \multicolumn{1}{c|}{} & $\begin{array}{c}\text { Resistance } \\
\text { variation } \\
\text { (\%) }\end{array}$ & $\begin{array}{c}\text { Material } \\
\text { consumption } \\
\text { (\%) }\end{array}$ \\
\hline $8 \mathrm{~mm}$ & -25.23 & -20 \\
\hline $12.5 \mathrm{~mm}$ & -14.69 & +25 \\
\hline $15 \mathrm{~mm}$ & -31.12 & +50 \\
\hline $20 \mathrm{~mm}$ & -50.37 & +100 \\
\hline
\end{tabular}




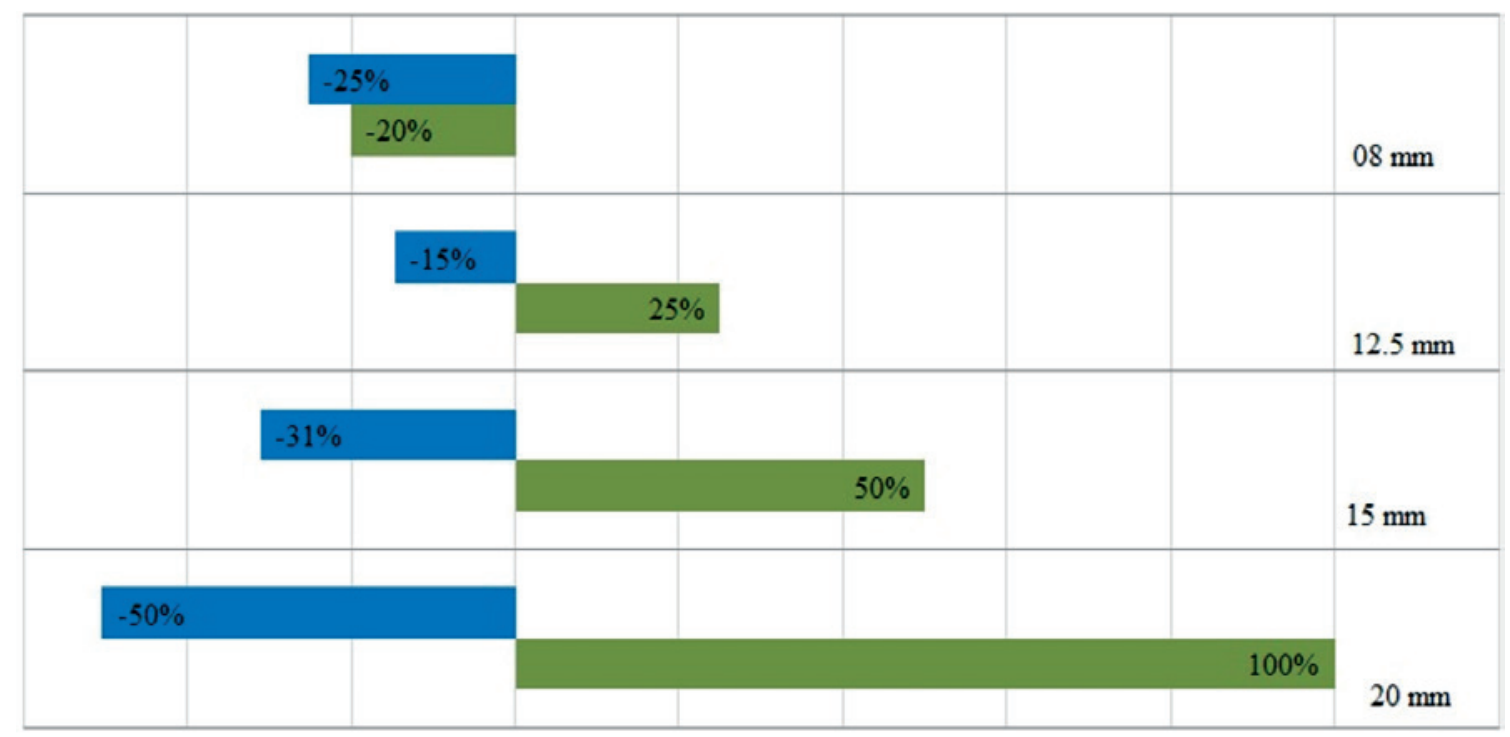

\section{घesistance Variation $\quad$ Material Consumption}

\section{Figure 9}

Performance comparative graph of thicknesses in relation to the $10 \mathrm{~mm}$ thickness

289 p. Ph. D. Thesis. School of Engineering of São Carlos, University of São Paulo, São Carlos, 2008.

[6] MOHAMAD, G. Comportamento mecânico na ruptura de prismas de blocos de concreto. 199f. Dissertação (Mestrado) Departamento de Engenharia Civil, Universidade Federal de Santa Catarina, 1998.

[7] DUARTE, R. B. Recomendações para o Projeto e Execução de Edifícios de Alvenaria Estrutural. ANICER, Porto Alegre, 1999.

[8] OLIVEIRA, M. H. Análise da resistência de prismas de blocos de concreto com variação da espessura das juntas de argamassa em alvenaria estrutural. 118f. Trabalho de conclusão de curso em Engenharia Civil, Universidade Estadual de Goiás, Anápolis, 2006.

[9] OLIVEIRA, H. R. Análise da Resistência de Prismas de Blocos de Concreto com variação da espessura das Juntas de Argamassa em Alvenaria Estrutural. TCC, Publicação ENC. PF- 034A/14, Curso de Engenharia Civil, Unievangélica, Anápolis, GO, 52p. 2014.

[10] BANDEIRA, B. N. Análise da resistência de prismas de blocos de concreto com variação da espessura das juntas de argamassa em alvenaria estrutural. 74f. Trabalho de conclusão de curso, Curso de Engenharia Civil, UniEvangélica, Anápolis, GO, 2014.

[11] SOUZA, A. G.; NUNES, P. P. Análise da resistência de prismas de blocos de concreto com variação da espessura das juntas de argamassa em alvenaria estrutural. 68 p. 81. Trabalho de conclusão de curso, Curso de Engenharia Civil, UniEvangélica, Anápolis, GO, 2015.

[12] FRANCISCO; A.M.X.; SOARES, H. A. B. Estudo da Influência das espessuras das juntas de argamassa em blocos de concreto na alvenaria estrutural. p. 81. Trabalho de conclusão de curso, Curso de Engenharia Civil, UniEvangélica, Anápolis, GO, 2016.

[13] ASSOCIAÇÃO BRASILEIRA DE NORMAS TÉCNICAS. NBR 6136: blocos vazados de concreto simples para alvenaria: requisitos. Rio de Janeiro, 2014.

[14] ASSOCIAÇÃO BRASILEIRA DE NORMAS TÉCNICAS. NBR 6118: projeto de estruturas de concreto: procedimento. Rio de Janeiro, 2014.

[15] ASSOCIAÇÃO BRASILEIRA DE NORMAS TÉCNICAS. NBR 12118: blocos vazados de concreto simples para alvenaria: métodos de ensaio. Rio de Janeiro, 2013.

[16] ROMAN, H.; MUTTI, C.; ARAÚJO, H. Construindo em alvenaria estrutural. Florianópolis: Ed. da UFSC, 1999.

[17] ASSOCIAÇÃO BRASILEIRA DE NORMAS TÉCNICAS. NBR 248: . Rio de Janeiro, 2013.

[18] ASSOCIAÇÃO BRASILEIRA DE NORMAS TÉCNICAS. NBR 7211: agregados para concreto: especificação. Rio de Janeiro, 2009.

[19] ASSOCIAÇÃO BRASILEIRA DE NORMAS TÉCNICAS. NBR 7215: cimento Portland: determinação da resistência à compressão. Rio de Janeiro, 1996.

[20] ASSOCIAÇÃO BRASILEIRA DE NORMAS TÉCNICAS. alvenaria estrutural: blocos de concreto: parte 2: execução e controle de obras. NBR 15961 - 2: Rio de Janeiro, 2011.

[21] CAMACHO, Jefferson Sidney. Projeto de edifícios de alvenaria estrutural. Notas de aula, Núcleo de Ensino e Pesquisa da Alvenaria Estrutural - NEPAE, Universidade Estadual de São Paulo, Ilha Solteira, 2006.

[22] Castro, Lucas Oliveira. Avaliação experimental da interação de paredes de blocos de concreto de alta resistência sob ações verticais. 163f. Dissertação Universidade Federal de Viçosa. Viçosa, MG, 2015. 
[23] VICENTE, Gabriel dos Santos; SANTOS, White José dos; BRANCO, Luiz Antonio Melgaço Nunes; BARBOSA, Ricardo Antônio. Análise experimental da influência da espessura da argamassa de assentamento no desempenho mecânico de prismas de blocos de concreto experimental. Revista Construindo, Belo Horizonte, v. 5, n. 2, Jul/Dez. 2013. 